UDC: 657.6

JEL Classification: M 42

ORCID: https://orcid.org/0000-0002-7696-256X

\author{
O. Yu. REDKO, \\ Dsc (Economics), Professor, \\ Certified Auditor, \\ National Academy of Statistics, Accounting and Audit
}

\title{
The Quality of Audit Cervices: Dreams and Illusions
}

A review of quality in the context of audit services leads to the conclusion that if the services fully conform to the customer's expectations, these services are quality ones. The quality of audit services is analyzed from the perspective of the Law of Ukraine "Audit of Financial Reporting and Audit Activities" from 21.12.2017. Analysis of factors differentiating customer expectations of the results of audit services allow for the conclusion that because quality requirements set by various auditors for the same audit service may differ, a single set of quality criteria cannot be elaborated.

It is argued that given the specifics involved in auditor services, their quality assessment would be a difficult matter. The argument is supported by extracts from the abovementioned Law. It is concluded that the Law, not containing a definition of the quality of audit services, puts emphasis on formal professional characteristics in the assessment of professional capacities of audit firms rather than results of their work.

It is shown that because the Law has no provisions about the auditor's right to own professional opinion, arbitrariness in the quality assessment of audit is legally fixed in Ukraine, opening doors for corruption.

Quality criteria for audit services are proposed, grouped by basic quality criteria and supplementary quality criteria. Factors preventing from fixation of price for audit services and from acceptance of price as a quality criterion are given. The reason why the criterion of staff number in audit firms cannot be used for quality assessment purpose is explained. The conditions that need to be put in place to have the quality of audit in Ukraine conform to social demands are highlighted.

Keywords: quality, Law of Ukraine "Audit of Financial Reporting and Audit Activities", audit services, audit firms, IFAC international standards of auditing.

What is the quality in a broader sense of view? Glossaries offer various treatments of this notion. According to the Encyclopedic Glossary of F. Brokgaus and I. Efron, "Quality is a combination of all the properties that make things different one from another". In the S. Ozhegov's Glossary of the Russian Language, "Quality is the existence of essential attributes and peculiar features that distinguish one thing from another". According to the Large Economic Glossary of the Institute of New Economy, "Quality is a combination of immanent features and characteristics of products and services, enabling them to satisfy the needs that are already specified or expected by customers of such products or services". Let us elaborate on the latter definition, because we believe it to the most relevant for the audit.

Resume 1. There is a circle of customers of audit services, with their needs in services. There is an expectation of certain characteristics, attributes, features etc. of these services. If the services rendered fully conform to the customer's expectations of these services, it means that the rendered services are quality ones. A gap between the fact and its expectations gives rise to the conflict of interest between an auditor and a customer of his professional services.

Quality of audit. Although in the Law of Ukraine "Audit of Financial Reporting and Audit Activities" 2258-VIII from 21.12.2017 (referred hereinafter as Law) all the professional services are divided into services on obligatory audit and non-audit services, we are going to elaborate on all the services, in their quality context, as an integrated whole.

In the series of our previous publications we showed, with reference to studies of the National Center for Accounting and Audit [1;2], that customers' expectations of the results of audit services are quite different. Differentiation of the expectations is essentially conditional on the following factors:

(C) O. Yu. Redko, 2018 
- Existence (or absence) of a conflict of interests between hired management and owners.

- Existence (or absence) of a conflict of interests between management and owners, on the one hand, and the State (represented by fiscal bodies), on the other hand.

- Existence of internal conflicts between the top management (structural units, more often the legal department) and the chief accountant (accounting department).

- Form of ownership (a private enterprise with one owner or an economic partnership with many owners).

- Type of activity (mono-business or diversified business).

- Imperfect, contradictory or mutually exclusive norms in the legal regulation of business.

- Existence of facts of fraud on the side of personnel, with unlawful economic transactions (mainly tax evasion).

Resume 2. Quality requirements set by various auditors for the same audit (or non-audit) service may differ to a large extent. It follows that a single set of quality criteria for audit services cannot be possibly elaborated.

Given the specifics involved in audit services, their quality assessment would be a quite difficult matter. It is as difficult to assess as the quality of work of a judge, a lawyer, a doctordiagnostician, a meteorologist, a prosecutor etc. Once the result of these professionals' work does not satisfy a customer for some subjective reasons, it means that the quality of their services is assessed as bad at private or social level.

It should be noted that neither of the Ukrainian Laws nor the Audit Chamber of Ukraine, the single regulator of audit work in Ukraine, contain a clear definition of the quality of audit (audit services). Even in the new Law elaborated by British for Ukraine there is Section VII "Quality Assurance of Audit Services", but there is no definition of what is the quality which needs to be assured by auditors according to the Law. When looking at paragraph 1, article 40 , it can be assumed that the quality of audit services should be understood as a combination of:

- the observance of the IFA international standards of auditing by audit firms and auditors;

- the observance of the principle of independence (with the word "professional" somehow missing)

- the effectiveness of the internal quality control system (with the effectiveness criteria somehow missing).

Therefore, Law did fix the right for inspecting the quality of audit services, but the inspection criteria were not specified. So, grounds for conflicts of interests in the audit community were laid and the doors for corruption opened.

It is hard to guess the Legislator's guidelines, but paragraph 10, article 40 of Law say that inspections of audit services shall be performed through testing (sic!):

- the practices with regard to the application of IFAC international standards of auditing;

- $\quad$ the observance of the principle of independence (most likely professional one);

- the scopes and quality of the used resources;

- the observance of the requirements on compensation (when these are fixed);

- the effectiveness of the internal quality control system;

- the authenticity of the information about transparence.

In keeping with the law-making practice in Ukraine, Law does not specifies the minimal scopes of the used resources, not to mention their "quality" (in all probability, human ones rather than technical or financial), nor does it fix the criteria of the effectiveness of internal control.

Irrelevance of Law to the Ukrainian audit practices is even more explicit in paragraph 10 , article 40, containing the requirement that the documents needed for quality inspection shall be selected in view of "analysis of risks of failure of an audit entity to fulfill an order for financial reporting audit in the scopes and by the procedures specified by IFAC international standards of auditing". However, no references are made to the elements of such risks and methods for their analysis. The national Legislator is in captivity to illusions that numbers of auditors (the more, the better), certificates issued by various professional public organizations or non-stop professional development are guarantees of the quality of audit services. 
However, the sad story of a series of loud scandals with international auditors of "the last four", both in Ukraine and abroad, gives clear evidence on vice versa.

Resume 3. Not giving a definition of the quality of audit services, Law puts emphasis on formal characteristics in the assessment of professional capacities of audit firms rather than results of their work. So, the reference is made to the resource side of the operation. When an audit entity, as a certified auditor, has office and sufficient staff, with the auditors engaged in non-stop professional development (respective certificates are at hand, with nobody checking the knowledge acquired), when IFAC international standards of auditing are practiced, the services of this audit entity will a priori be judged as quality ones.

But what is about the auditor's right to own professional opinion?

Resume 4.

Arbitrariness in the assessment of quality of work of an audit entity has been legally fixed in Ukraine, a country where arbitrariness opens doors for corruption.

At the same time, means for protection against arbitrariness are not provided in Law.

What can be quality criteria for audit services? It appears that there can be several quality criteria for audit services. We believe that all the quality criteria can be divided into basic and supplementary ones. The observance of basic criteria can assure the minimally accepted (marginal) quality of professional services, whereas supplementary criteria are intended to increase the minimal quality.

We understand that the notion "minimal quality" is a conditional one. We believe that basic quality criteria for professional services should include the following:

- regular observance of the professional ethics by an auditor (including professional independence, confidentiality etc.);

- "operative" professionalism: argumentativeness and justification of results of audit or consultations; soundness, absence of interpretations etc.; professional organization of business process;

- application of IFAC international standards of auditing in view of customer orders and customer expectations;

- observance of the norms of the Ukrainian law.

Supplementary quality criteria can include:

- insurance of auditor risk;

- level (availability) of the auditor's professional education and professional experience (including certificates on professional development);

- level of computerization of the processes involved in professional services.

The analysis of practices of quality control in Ukraine gives evidence of the priority of compliance with the norms of IFAC international standards of auditing. But the right of an auditor for own professional opinion is, in fact, ignored. If combined with interpretations of the situation by inspecting controllers, this approach does not encourage higher quality of audit services; it, instead, gives rise to conflicts of interests and lays grounds for corruption. The analysis of complaints on Ukrainian auditors shows that their lion share consists of claims from government regulators of the securities and financial services market. It means that complaints tend to come from indirect customers of services rather than direct ones. The objectivity of complaints raises much doubt and may lead to the conclusion about unfair competition and corruption, because the abovementioned regulators keep the register of audit firms admitted to markets.

Resume 5. The probability of correct assessment of audit quality by an external controller will not be high unless a customer of audit services is checked (repeated audit of the reporting). Therefore, external checks of formal professional attributes of an audit entity remain the main form for quality control. The Ukrainian practice of external quality control is not prone to accept the auditor's right for not finding substantial inconsistencies in reporting data and tends to ignore the auditor's right for own professional opinion, although both principles are declared in IFAC international standards of auditing.

Many national auditors complain on price dumping by their colleagues and demand that the size of fees in an audit firm be accepted as a quality criterion. This approach is unfeasible due to the following reasons:

- Not all the customers can afford high fees to audit firms given the obligatory audit of reporting. Of 2 million business entities in Ukraine, nearly 1200 provide for 85 to 
90 percent of tax revenues to the budget. The rest have far lower financial capacities for audit purposes.

- $\quad$ Price dumping can be detected given the fixed minimal price for audit. If it does not exist, reference to dumping would be incorrect.

- Two orders for audit of reporting with identical names cannot be compared (at least in Ukraine) if even the financial capacities of customers are the same. There are many factors setting price of audit services: practices and performance of accounting, accountants' skills and qualifications, relations between owner and management, organization of management system, availability and quality of resources in an audit firm.

Regulatory bodies in Ukraine are prone to use the criterion of the number of auditors in staff of audit firms in their regulatory acts, in order to have the staff number linked in a way with the quality of audit services. This is a full nonsense which, unfortunately, is fixed in new Law. It means a priori that the more numerous is the staff, the more expensive are the professional services. This approach has not been subject to a scientific study, nor does it have a logical argumentation. There cannot be meaningful answers to rhetoric questions like the following:

- Why 10 staff auditors are better than 5 or 3 ?

- Why the quality of services rendered by young auditors with certificates from international professional organizations are higher than the quality of services offered by auditors with 10 years of excellent professional carrier but without such certificates?

The author's standing is that a quality auditor (excellent auditor) is a singular phenomenon. His professional training and formation can take years. Besides that, a sufficient life experience (age) is required, which is essentially important given the corrupted business environment in Ukraine.

It should be mentioned in the context of the above that Law does not contain norms that would allow for "collective" audit with inviting outside audit firms and auditors on outsourcing basis (collaborative work). If they were included, it would give a real chance to combine the capacities of best professionals for the time of the order execution, thus increasing the likeliness of high quality of the professional services.

Resume 6. The author's experience of work in the Audit Chamber of Ukraine (19982011, 2017-2018) and personal professional practice confirm that the following conditions need to be in place to have the quality of professional services of Ukrainian auditors conform to the social demands:

- Audit entities in Ukraine need to engage in audit services as business professionals rather than amateurs in secondary jobs. Professionalism in audit business means the financial result that allows to expand the material capacities of an audit firm, and to enhance the competencies of its personnel.

- Clear quality criteria (if even formal) for professional services, which are fixed legally and cannot be interpreted by inspecting controllers or official regulators of sectoral markets.

- A national program for quality assurance in audit services, devoted to: (i) training and setting up the system for internal quality control in audit entities; (ii) propagation of requirements for quality of audit among the customers of obligatory audit in the first place, and voluntary audit; (iii) the established institute of professional controllers of the quality of audit services.

We believe that the above conditions can be introduced in a longer term and with the political will, but this vector of development of the Ukrainian audit would be more advanced than the one adopted now in the Law "Audit of Financial Reporting and Audit Activities". Meanwhile, the illusions about quality of audit services remain.

\section{References}

1. Redko O. Iu. (2013). Instytualizatsiia ukrainskoho audytu. Mify ta realnist [Institutionalization of the Ukrainian Audit. Myths and realities]. Visnyk Chernihivskoho Derzhavnoho tekhnolohichnoho universytetu. Seriia "Ekonomichni nauky" - Bulletin of Chernihiv State Technological University. Series "Economics”, 3 (68), 209-212 [in Ukrainian]. 
2. Redko O. Iu. (2014). Audyt v Ukraini. Prahmatyka korystuvacha [Audit in Ukraine. Pragmatics of a user]. Bukhhalterskyi oblik $i$ audit-Accounting and audit, 9, 37-43 [in Ukrainian].

О. Ю. РЕДЬКО доктор економічних наук, професор, сертифікований аудитор, Національна академія статистики, обліку та аудиту

\section{Мрії та ілюзії про якість аудиторських послуг}

Якість аудиторських послуг в Украӥні проаналізовано в світлі Закону України “Про аудит фінансової звітності та аудиторську діяльність" від 21.12.2017 р. Вказано проблеми, пов'язані з очінюванням якості аудиторських послуг, які проілюстровано на окремих положеннях згаданого закону. Запропоновано критерії очінювання аудиторських послуг. Обтрунтовано фактори, щзо перешкоджають встановленню фіксованих иін на аудиторські послуги, а також прийняттю критеріїв ціни на аудиторські послуги та кількості персоналу в аудиторських фірмах для оцінювання якості аудиторських послуг. Названо умови, за яких якість аудиту в Україні відповідатиме запитам суспільства.

Ключові слова: якість, Закон Украӥни "Про аудит фінансової звітності та аудиторську діяльність", аудиторські послуги, аудиторські фірми, міжнародні стандарти aydumy IFAC.

А. Ю. РЕДЬКО,

доктор экономических наук, профессор, сертифицированньй аудитор,

Национальная академия статистики, учета и аудита,

\section{Мечты и иллюзии о качестве аудиторских услуг}

Качество аудиторских услуг в Украине проанализировано в свете Закона Украины «Об аудите финансовой отчетности и аудиторской деятельности» от 21.12.2017 2. Указаны проблемы, связанные с оцениванием качества аудиторских услуг, которые проиллюстрированы на отдельных положениях упомянутого закона. Предложень критерии качества аудиторских услуг. Обоснованы факторы, препятствующие установлению фиксированных иен на аудиторские услуги, а также принятию критериев цены на аудиторские услуги и количества персонала в аудиторских фирмах для оченивания качества аудиторских услуг. Названы условия, при которых качество аудита в Украине будет соответствовать запросам общества.

Ключевые слова: качество, Закон Украинь «Об аудите финансовой отчетности и аудиторской деятельности», аудиторские услуги, аудиторские фирмь, международные стандарты аудита IFAC.

Bibliographic description for quoting:

Redko O. Yu. (2018). The Quality of Audit Cervices: Dreams and Illusions. Scientific Bulletin of National Academy of Statistics, Accounting and Audit-Naukovyi visnyk Natsionalnoi akademii statystyky, obliku ta audytu, 3, P. 34-38 [in English]. 